\title{
Alpha-3 Country Code
}

National Cancer Institute

\section{Source}

National Cancer Institute. Alpha-3 Country Code. NCI Thesaurus. Code C54642.

The three-letter country codes specified by the ISO 3166-1 country code standard. 